\title{
РУКОПИСНЕ ПЕСМАРИЦЕ У ДОБА СРПСКОГ РОМАНТИЗМА
}

1. Рукописне песмарице су занимљива, не баш сасвим неважна, проучавана, али не и сасвим проучена књижевноисторијска и културноисторијска појава. У свеске, различитог изгледа и порекла, људи су бележили стихови да би их за себе сачували од заборава или да би их поклонили неком блиском; бележили су песме по сећању, онако како су их чули од других, или су их преписивали. Оне су лични, понекад сасвим интимни избор. Међутим, од збирке до збирке понављали су се записи истих песама, а та је поновљивост таква да се може говорити о традиционалном фонду песама у рукописним песмарицама. Рукописне песмарице су сведочанство о својим састављачима и власницима, али истовремено и документ о времену.

1.1. Ти рукописи сведоче сами о себи - својим изгледом, избором песама, ретким и штурим белешкама - а мало је других података о њиховим власницима и састављачима, околностима, месту и времену настанка, о мотивима и начину бележења и о изворима сазнања о песмама. Неизвесно је да ли их је било у XVII веку, документована историја њихова почиње заправо Ерлангенским рукописом и Песмарииом Теодора Добрашевића (1763), а обичај се полако и неумитно гаси око 1870. године. Последња мени позната песмарица датирана је 1892. године, а делује као трагикомичан анахронизам. ${ }^{1}$ Када би се узело у обзир да су рукописне

1 Будући да је крај једнако важан као и почетак за истраживање књижевноисторијских појава, а да се ради о досад сасвим непознатом рукопису, доносим овде неколико података о овој песмарици. Песмарица Стевана Видаковића налази се у Рукописном одељењу Матице српске у Новом Саду под сигнатуром М 9.980. Ради се о рукопису од 46 листова, увезаном у картон. Насловна страна Пјесме. Записивач песама и власник рукописа Стеван Видаковић потписао се с унутрашње стране корица, на л. За стоји 1892. година, а на л. 1а неко је записао накнадно „Стеван Видаковић, Врдник”. У песмарици је забележено 26 песама и као мото четири стиха једне песме. То су, без ознаке имена аутора, песма Ј. Рајића, J. Стерије Поповића, Ј. Хаџића, J. Драшковића, В. Живковића, М. Попо- 
песмарице трајале бар онолико колико и људи који су их чували, требало би закључити да се на заласку епохе романтизма рукописне песмарице престају стварати, а да се њихова функција (разлози њихова постојања) гаси на размеђу два века.

1.2. Досад су српске рукописне песмарице изучаване у вези са грађанским песништвом јер „... је грађанско песништво све оно што није штампано у књигама и различитим другим повременим списима него се сачувало у старим рукописима и рукописним песмарицама". Уколико се односи на XVIII век, ова је тврдња углавном тачна; што се више улази у XIX век, она све више губи од своје тачности. Грађанско песништво, оно које је створено у XVIII веку, прелази једним својим делом у Гутенбергову галаксију: песме се штампају у часописима, новинама, календарима, алманасима, песмарицама, лирама и другим публикацијама, а у рукописне песмарице се, поред класичних грађанских песама (називамо тако, за невољу, оне песме настале у XVIII и првим деценија XIX века), уписују новостворене песме, класициста, предромантичара и романтичара. У досадашњим проучавањима главна је пажња усмерена ка XVIII и почетку XIX века, што је разумљиво и оправдано. ${ }^{3}$

1.3. У овом раду реч је о рукописним песмарицама у српској књижевности у времену од 1830. до 1870. године, које се може назвати добом романтизма, условно и уз нужни опрез који захтева свако хронолошко омеђавање књижевних праваца. Намера ми је да прикажем рукописне песмарице у најопшијим цртама, њихову распрострањеност, изглед и садржај. Није прилика да се о рукописним песмарицама сада пише на другачији начин; то ће бити могуће тек када се обаве заметна и пипава истраживања, која би требало да обухвате описе појединих песмарица, трагање за ауторима песама, жанровско одређење, опис метрике, стране узоре и изворе и др.

вића, Ђ. Јакшића и других аутора, чија имена нисам успела да откријем. Ова је песмарица, са незнатним изузецима, избор из патриотске лирике инспирисане 1848. годином, а све забележене песме јављају се и у раније датираним рукописним песмарицама.

${ }^{2}$ М. Лесковац, Српско грађанско песништво XVIII века, Летопис Матице српске, 1946, цит. према Чланци и есеји, Нови Сад, 1949, 10.

3 За проучавање грађанског песништва три су дела незаобилазна: Т. Остојић и В. Ћоровић, Српска грађанска тирика XVIII века, Београд-Ср. Карловци, 1926; М. Лесковац, нав. дело; Б. Маринковић, Српска грађанска поезија XVIII и с почетка XIX столећа I-II, Београд, 1966. У предговору овој књизи дат је инструктиван преглед дотадашњих изучавања грађанског песништва и рукописних песмарица. 
2. Свако истраживање рукописних песмарица суочава се са тешкоћама око библиографског пописа и описа ове врсте грађе, а откривање сваке нове песмарице, ако и не мења основна сазнања, свакако их допуњује и коригује низом малих и ситних података, које треба слагати у целовиту представу. На прво од питања које је потребно поставити - колико је сачуваних рукописних песмарица (уопште или из времена о коме је овде реч) - нисам у стању прецизно да одговорим. Као грађа за овај рад послужиле су ми досад познате песмарице које су настале од 1830. до 1870. године и деветнаест потпуно непознатих, међутим, поуздано знам да се број сачуваних песмарица овим не завршава. ${ }^{4}$

2.1. Сви су ти рукописи били лично власништво, понекад су - може се то без много довитљивости открити - рукописне песмарице биле сасвим интимног карактера. У Песмарици Петра Лончара Вукова, поред махом љубавних песама, налази се концепт љубавног писма некој „слаткој Каћи"; безмало ни једна од песама забележених у Песмарици Александра Бана није била за показивање нити за певање у пристојном друштву; скоро све песмарице настале после 1848. године обиловале су патриотским стиховима немоћног и запенушеног беса и разочарања, те су у време

${ }^{4}$ Најпотпунији попис рукописних песмарица дао је Боривоје Маринковић. Из његовог Пописа извора користила сам приступачне рукописне песмарице које су означене бр. 67-107 (нав. дело II, 225-261) и још деветнаест нових, од којих сам највећи део пронашла у Рукописном одељењу Матице српске. Будући да је у оквиру научног пројекта Уметничка и народна поезија у у рукописним песмарицама XVIII и прве половине XIX столећа (пројекат се ради у Институту за југословенске књижевности Филозофског факултета у Новом Саду под руководством Б. Маринковића) у завршној фази припреме попис рукописних песмарица, доносим овде само списак досад непознатих, односно оних које сам сама пронашла, чија сам садржај проучила и које користим у овом раду: 1. Песмарииа Григорија Грујића (1836-1837), 2. Кюижииа Саве Коларовића (1837); 3. Песмарииа Василија Петровића (1842), 4. Песмарииа Михаила Николајевића (1845), 5. Песмарииа Глигорија Војновића (1846?-1868), 6. Песмарииа Симеона Мајинског (1847), 7. Песмарииа Михаила Димитријевића (1848), 8. Песмарииа Петра Лончара Вукова (1850), 9. Српска тира Славка Видака (1857), 10. Песмарииа Стебана Видаковића (1857-1859), 11. Песмарииа Василија Георгијевића (1859), 12. Песмарииа Василија Николајевића (1860), 13. Песмарииа Марије Николајевићеве (1866-1875), 14. Песмарица благоразумне господичне Анастазије от Матијевич (средина XIX века), 15. Песмарица Ђоке Ваића (средина ХIX века), 16. Песмарииа Светозара Белеслијина (средина XIX века), 17. Песмарииа М. Д. Дејановића (средина XIX века), 18. Песмарииа Јебте Цуиића (средина XIX века), 19. Песмарииа Саве Петровића (средина XIX века). У оквиру поменутог пројекта откривено је још рукописних песмарица, али ни то, вероватно, није све. 
Баховог апсолутизма, вероватно, припадале инкриминисаним списима. Изгледом се рукописне песмарице разликују онолико колико се и иначе људске рукотворине међусобно разликују. То су или свеске направљене од прошивених листова или занатски радови књиговезаца. Писано је или „на оној жућкастој, рапавој, а униформној и јефтиној хартији XVIII века" или на нешто бољој и бељој, понекад чак луксузној хартији, са ивицама које имитирају чипку или са уштампаним цветићима.

У свој тој великој разноликости има и сличности, тако да би се рукописне песмарице настале од 1830. до 1870. године, према изгледу, распореду уписаних песама и намени, могле сврстати у три групе. Прву групу чиниле би оне које бих радо назвала „сваштарама”, по угледу на онај познати тип ђачке свеске. Оне су изгледом најскромније, писане често у журби, са намером да се имају при руци песме до којих је власнику стало; у њих су бележене песме за своју душу, без икаквог реда и поретка, а поред песама и све оно што је власнику било важно или му на ум пало. Арсеније Ћирић је на песмарици, која је некад, највероватније, припадала старијем ђаку Георгију Деспоту, дечјим рукописом и у дечјој сујети четири пута записао: „Живио Арсен Ћирић”, али и: „Г. Марковићу 1 пар” - ципела или чизама, претпостављам, јер је Арсеније Ћирић био обућар. Василије Николајевић је на крају једне стране своје песмарице уписао: „Јелена Милутинович отиде к Г[оспо]ду дне 15. марта 1860," или зато што га је ова смрт потресла, или да доцније упише тачан датум у матице умрлих, што је као свештеник био дужан да учини. Овако би се набрајати могло у недоглед. Ове су рукописне песмарице прави настављачи традиције XVIII века и њих је међу сачуванима највише.

Други је тип песмарица-споменар; то је рукописни зборник поезије који се саставља за другога, па се, као и сваки поклон, брижљивије бира и опрема. Песмарица Марије Николајевићеве мала је књижица, увезана у црвени сомот, на корицама има иницијале власнице и њен зодијачки знак, а затвара се копчом. Насловна јој је страна: „Песмарица Марије В. Николајевићеве, рођене Остојић, поклон од супруга Василија Николајевића, свештеника". У знак супружанске оданости Василије Николајевић прибавио је и калиграфски исписао текстове сто и четрдесет песама. Песмарииа Јулијане Брежовски имала је више приложника, а кад је госпођиначка фрајла постала Јулијана Иванић, песмарица је доживела неславан крај: свештеник Ђорђе Иванић је од романтичне књиге, будући да је била од добре хартије и солидно увезена у полуплатно, направио своју бележницу, у коју је записивао концепте писама, слова која је држао о неким црквеним празницима и друго у вези са црквом. Богослов Светозар Пантелић наменио је „благородним госпођицама Јелисавети, Јоси- 
фи и Розини Ауер у знак високог поштовања" једну песмарицу, у коју су прилагала још најмање двадесет и четири супотписника, највероватније из редова карловачких гимназијалаца и богослова, којима је и Пантелић припадао. Стефан Видаковић је уз сваку песму у своме рукопису забележио којој је од драгих му господични намењује.

Трећем типу песмарица припадале би оне које су инспирисане штампаном књигом. Заједничко им је спољашње обележје да све делују као „начисто преписане” и имају садржај (содержаније, исказ песана). Такве су песмарице С. Коларовића, М. Николајевићеве, Н. Беговића, С. Мајинског, М. Ивачковића и С. Петровића. За песмарице Н. Беговића и С. Петровића могло би се претпоставити да су биле припремане за штампу. Н. Беговић је доцније публиковао народне песме, а С. Петровић је своме рукопису дао наслов Збирка разних народних песама што се певају и опскрбио га, једини од свих власника песмарица, именима аутора. Ове песмарице представљају последњи ступањ у развоју: опонашајући књигу, оне признају супериорност штампане речи и сопствену излишност.

Намена песмарице није битно утицала на њен садржај, нити на начин бележења. Разлике у садржају између појединих типова песмарица резултат су пригодног избора из постојећег фонда песама, а у начину бележења скоро и нема разлика. Имена песника и наслови песама последња су брига записивача; имена аутора записују се сасвим ретко, а песме се најчешће обележавају бројевима и простом одредницом песма (пъсма, пъснъ, пъсна). Да ли је та небрига за име аутора значила и његову потпуну анонимност, тешко је рећи, али је сасвим сигурно да је податак о томе по коме се гласу која песма пева за власнике песмарица био много драгоценији. Многе су песмарице без наслова, или се насловна страна изгубила, некима је наслов једноставно песмарица. Понеке су насловљене опширније: Различите серпске песме употреблајеме от младости ради увеселенија (А. Бан), Кюижица која у себи различне песме содержава (С. Коларовић), Сабране разне песме српске (Михаило Николајевић), Народне серпске песне за увеселеније заљублени' страна и оних који весељье љьубе (Н. Беговић), Песмарииа која содержи у себи разни' сепрскиј песама (С. Мајински), Збирка разних народних песама што се певају (С. Петровић). Међутим, и ту влада одређена униформност: за састављаче песмарица битне су одреднице „разне песме”, „српске песме”, „народне песме” и „увеселеније”. Уз напомену да ознака „народна” (било да се јавља у наслову песмарице, или песме) значи: „популарна”, „радо певана” или „намењена народу”, а никако „традицијска, усмена”, може се рећи да су наслови песмарица углавном верно осликавали њихов карактер. Песме су биле српске бар по томе што су у разним варијантама српског 
језика реализоване; по теми, облику и пореклу песме су се стварно једна од друге разликовале, а да су служиле за увесељење најбоље су знали, ваљда, они који су се њима служили.

2.2. Територија на којој су настале песмарице из времена од 1830. до 1870. године, према ономе што се досад могло открити, омеђена је следећим местима: Сремски Карловци (Песмарица Александра Бана, Песмарица Светозара Пантелића и највероватније Песмарица Александра Ракића, Песмарииа Симеуна Мајинског и Песмарица Глигорија Војновића) - Голубинци (Песмарииа Марије Николајевићеве) - Рума (Г. Војновић је из Руме, а школовао се у Сремским Карловцима) - Јазак (Песмарица Стефана Видаковића) - Сремска Митровица (Песмарица Павла Панајотовића) - Шид (В. Георгијевић је из Шида) - Обровац (Песмарица Јована Поповића) - Сириг (Песмарица Светозара Белеслијана) - Госпођинци (Песмарииа Јулијане Брежовски) - Нови Сад (Песмарииа Арсенија Ћирићa), а изван тог круга остају Ђаковица (Песмарица Илке Тонина), Костајница (Песмарица Николаја Беговића), Баја (Песмарица Василија Георгијевића) и Темишвар (А. Ракић је из Темишвара). Наведено би упућивало на закључак да је рукописно записивање песама било обичај на територији Карловачке митрополије, ближе њеном средишту нарочито. Будући да у многим песмарицама није наведено место настанка и да су многе нетрагом изгубљене, могуће је да се само стицајем прилика сачувао највећи број песмарица из Сремских Карловаца.

2.3. Међу власницима песмарица и њиховим састављачима највише је ђака, а од ових богослова: Георгије Деспот, који је вероватно састављач рукописа названог Песмарица Арсенија Ћирића, потписао се као „уч. IV грам. класе”; К. Поповац, супотписник исте песмарице, као „II човеческе школе слушатељ”, а Александар Бан као „уч. III латинске школе”; судећи по рукопису, Арсеније Ћирић, Јован Ваић, и Александра Поповић били су деца кад су дошли у посед туђих песмарица. Као богослови почели су да састављају песмарице С. Мајински, Н. Беговић, Г. Војновић (доцније епископ темишварски), Т. Милованов (један од приложника Песмарице Јулијане Брежовски), А. Ракић, С. Петровић, С. Пантелић и неко од његових другова. Богослови су обичај, можда, наставили и као свештеници. Свештеник Василије Николајевић саставио је две велике песмарице, прва има потписе још неких Николајевића, највероватније из његове уже фамилије, а другу је поклонио супрузи. Љубитељи рукописних песмарица били су учитељи (J. Поповић, Т. Милованов, Н. Беговић, X. Томић) и бележници (С. Белеслијин, М. Николајевић, С. Видаковић). „Купечески калфа" Сава Коларовић саставио је једну песмарицу, а обућарски шегрт Арсеније Ћирић користио је једну ђачку. Најзад, у Песмарииу Јулијане Брежовски уписивао је стихове М. П. Цветић, „члан срп. нар. позоришта 
у Н. Саду”. Међу власницима песмарица су, у овом периоду први пут, и жене: девојчица Александра Поповић, три благородне госпођице Ауер, благоразумна Анастазија от Матијевић и попадије Јулијана Иванић рођ. Брежовски и Марија Николајевићева. Има у тим песмарицама-споменарима много романтичног духа и њему својствене жеље да се „српске кћери” уведу у поетски свет, нарочито онај србујући и љубавни.

Ниједно од имена власника и састављача песмарица није значајно, овде су наведена да покажу социјални миље у коме рукописне песмарице настају. У закључивању о њему била бих сасвим обазрива. Рукописне песмарице су обичај ђачког доба и младих људи; заједно са песништвом које негују, оне припадају грађанском сталежу, и то претежно оном његовом делу који је по својој професији више упућен на писану реч. Приметно је мали број занатлија и трговаца. Да ли су „буквонеискусни бербери, фелчери, дућанџије и њихове калфе, занатлије свих врста, војници" имали својих песмарица, па се оне нису сачувале, или су ти људи више били упућени на усмено преношење омиљених им стихова - питање је на које не могу да одговорим.

3. Творци рукописних песмарица показали су доста свести о сопственом укусу када су своје рукотворине насловљавали са „различите песме”. Не постоје две идентичне песмарице (по садржају уписаних песама, њиховом распореду и броју), а нема ни такве која би се могла назвати самосвојном. Унети у приказ тог хаоса од стихотворенија било какве прегледности чини се немогућим послом јер се записиване песме међусобно по свему разликују, по садржају, облику, жанру, језику, метричким обележјима и провинијенцији, а много их је. Чини се да је овом приликом могуће говорити о фонду рукописних песмарица само по критеријуму провенијенције песама. Неопходно је при том претходно нагласити да свака песмарица у свом фонду записаних песама има елемената уобичајеног, готово би требало рећи традиционалног, и индивидуалног: фонд песама који се користи у рукописним песмарицама је традиционалан, или је такав бар највећим делом, а индивидуалан је избор из оног што се по традицији у песмарице записује, индивидуалан је распоред песама и евентуално један број уписаних песама. Једноставно речено, нису сви преписивали све песме које су важиле за популарне, сви су правили некакав избор из датог и томе по сопственом нахођењу додавали понеку нову песму. Ствар се, даље, компликује тиме што је свака новооткривена песма имала, под одређеним условима, шансе да постане део фонда омиљених песама.

Док се, дакле, неко не прихвати заметног и дангубног посла да утврди жанрове у грађанском песништву, могуће је говорити, у најопштијим

${ }^{5}$ М. Лесковац, нав. дело, 11. 
цртама, о три групе песама које су бележене у рукописне песмарице: о грађанском песништву, уметничкој (пасивној) и народној (усменој) поезији. И ову је поделу могуће примењивати само у грубим границама и уз извесну меру субјективности. Почев од термина грађанско, народно и уметничко песништво и њихове дефиниције, до метода описа појединих песничких појава и критеријума за њихово међусобно разлучивање, све је спорно и све се може доводити у питање. Кад се ради о записима у рукописним песмарицама ствар се још више компликује јер сами састављачи песмарица нису нимало држали до порекла песама; бележили су их без икаквог реда, онако како су их добијали, по некаквом асоцијативном низу, или по тематским скупинама.

3.1. Бележећи у своје песмарице стихове грађанског песништва, оне настале у XVIII и првим деценијама XIX века и скоро по правилу анонимне, састављачи песмарица из средине XIX века показали су се као приљежни чувари традиције, или бар једног њеног дела. Од песама које су створене и преписивањем ширене пре 1817. године, око половина преживљава у песмарицама насталим у времену од 1830. до 1870. године. ${ }^{6}$ Без обзира на то што је популарност старих песама у новијем времену различита, што значи да се све песме грађанског песништва не преписују подједнако често, чињеница је да један део успостављеног фонда егзистира и даље и она говори у прилог закључку о традиционалности рукописних песмарица. За испитивање дијахронијског развоја рукописних песмарица битно би било установити које песме остају популарне, а које тону у заборав. О томе је сада могуће говорити само на основу утиска. Најпре падају у заборав религиозне песме, нарочито оне лишене пригодног карактера, а затим песме историјско-патриотске

${ }^{6}$ Иако не верујем у могућност и сврсисходност примене статистичког метода у истраживању књижевноисторијских појава, до овог сам закључка дошла рачунањем. Постојећем списку од 609 песама које припадају грађанском песништву (Б. Маринковић, нав. дело II, 281-521) додала сам податке из досад непознатих деветнаест песмарица, а затим издвојила песме које су настале пре 1817. године и које су преписиване у песмарице настале после 1830. године. Израчунавање је показало да 50,33\% песама наставља да живи и после 1830. године. Свесна сам замерки које се оваквој рачуници могу ставити. Овде се ради о случајном узорку - пука је игра животних случајности што су сачуване баш ове, а не неке друге, рукописне песмарице, са другим садржајем. Затим, податак је непрецизан и у овом смислу: од ових 50,33\% „преживелих” песама неке су након 1830. године забележене само једанпут, што може бити случајно, а свакако је ствар личног укуса и обавештености записивача, а неке се находе у скоро свим песмарицама. Разлог што ову крњу рачуницу ипак износим на видело у томе је што ми се чини бољим и то од изношења произвољног утиска. 
инспирације; најдуже се чувају љубавне песме. Религиозно осећање све мање заокупља грађанина XIX века, па и као поетска тема, а стари фонд историјских, патриотских и војничких песама бива замењен, нарочито после 1848. године, новим и актуелним песмама истог жанра. Рекло би се да је заинтересованост за тему, заправо за могућност примењивања песме на животне околности свакодневице, од већег утицаја на популарност и опстанак песме но стил и поетски језик. У погледу поетског језика могао би се изнети утисак да се он „поправља” у смислу захтева Вукове реформе и по узору на усмену поезију. Постојање и омиљеност мелодије утиче свакако на боље упамћивање и дуже одржавање песме.

3.2. Тзв. уметничка, односно писана, поезија одувек је бележена у рукописне песмарице; у времену од 1830. до 1870. године ова је традиција настављена, а у песмарице су бележени и стихови многих нових песника. Песника чији се стихови усменим путем и преписивањем шире много је, а за састављаче рукописних песмарица они су, бар у једном, сви једнаки: сви су анонимни, једнако безимени и необележени као и творци грађанског песништва. Док се не ураде пописи свих песама у свим рукописним песмарицама, о томе чији су све и какви стихови били радо бележени и у рукописима чувани од заборава, могуће је говорити само у виду површног и непотпуног прегледа. Питање је, заправо, да ли ће се аутори неких песама уопште и открити, а сигурно је да ће се пред оним ко се у том циљу упусти у прелиставање књига и различитих других публикација испречити питање смисла тог мукотрпног посла, јер се у већини случајева ради о песницима мале или никакве вредности.

У рукописне песмарице бележени су стихови најразличитијих песника, представника различитих стилских формација и сасвим неједнаких домета, од оних који обележавају епоху, до оних чија имена ништа не значе ни најбољим зналцима књижевне историје. Нису све песме које су биле записиване биле једнако популарне, ако се може судити по учесталости бележења. ${ }^{7}$ Преглед често преписиваних песама показује да је традиција старих песмарица оставила и на новима неког трага: песме

7 Доносим овде један преглед често преписиваних песама, уз напомену да треба имати у виду оно што је написано у претходној фусноти.

Песма (према првом стиху)

1. М. Видаковић, Светли месеи, иза горе

2. Доситеј, Све што мене окружава

3. С. Јовић, Сећаш ли се оног сата
Број песмарица у којима се јавља у \% 
Стерија, Сакриј бледе твоје зраке 44,82

4. Ј. Суботић, Ја сам млада Српкиюа

В. Живковић, Ти плавищ, зоро златна

5. М. Видаковић, Ах престан'те невине 37,93

6. М. Орешковић, Праг је ово милог српства 34,48

7. М. Видаковић, Појте, миле и тубезне

В. Живковић, Радо иде Србин у војнике

8. Н. Грујић, Гди Фрушка Гора у Дунав силази

В. Николић, Куд погледим свуд је тама

Ј. Суботић, Ја сам Србин

9. Ђ. Бошковић, Младо пастирче умилно

М. Видаковић, У месту пријатном, тихој пустиғи

В. Живковић, Радуј се, млада нево

Ђ. Јакшић, Ране моје туто тиште

С. Милетић, Већ се српска застава

М. Обреновић, Што се боре мисли моје

Ђ. Николић, Како може душа твоја

Ј. Суботић, Зашто да се ја бринем

10. В. Живковић, Српске кћери чарнооке

Ђ. Николић, Што се суние, ияар на небу

М. Орешковић, Војводину гроб покрива

11. В. Живковић, Већ из густог луга

М. Орешковић, Тећ’ ће вода куд је текла

М. Поповић, Сабъо моја димискијо

Стерија, Слатка туго сриа мога

Стерија, Устај, устај, Србине

Ј. Суботић, љубио се бео голуб

И. Трнски, Ој таласи мили, 'ajmе

12. Ђ. Бошковић, Расло јеленче малено

В. Васић, Што ћутиш, Србине тужни 
писаца старије генерације, које постоје у песмарицама насталим пре 1830. године, преписују се и даље, а од оних новије генерације на цени су песници меких и идиличних расположења, творци родољубивих и србујућих стихова, песме инспирисане 1848. годином. Избор из песничке продукције, савремене и старије, показује да се укус окретао све више у правцу сентиментализма, ако није сентиментализам превлађујући стилски комплекс од самих почетака грађанског песништва, и да је такав остао и у време које се сматра победом романтизма у српској књижевности, након 1848. године.

3.3. У усмене песмарице бележене су лирске усмене песме, уз занемарљиво мали број балада. Највише је усмених љубавних песама, а затим сватовских. Ова бележења усмених творевина постојала су и у предвуковском времену у развоју песмарица; ова је традиција настављена, али на други начин. У времену од 1830. до 1870. године у рукописним песмарицама врло често су преписивани стихови из Вукових збирки. Постоје, међутим, и изворни записи, који су изузетно драгоцени, бар из два разлога. Прво, ради се о песмама са терена који Вука није посебно занимао (територија данашње Војводине), те о песмама о којима је говорио с подсмехом и презриво (ирошке песме, бећарци). Друго, међу несистематично записиваним песмама усмене лирике у рукописним песмарицама има и изванредних остварења.

М. Видаковић, Багрјаношарна от востока зарја

М. Видаковић, Све сам благо овог света

Ј. Јовановић Змај, Соко бира ди ће наћи мира

С. Лазић, Чашииама, песмииама

Л. Мушицки, Днеј, радостних, печалних

Никола I, Онамо, 'намо за брда она

13. Н. Грујић, Луло моја, разбибриго

Ј. Драшковић, Тко је рођен Славјан

Ј. Јовановић Змај, Нема таке луле

Ј. Јовановић Змај, Уз'о деда свог унука 10,34

Д. Михајловић, Гром и пак'о, браћо драга

М. Орешковић, Чуј, дико, ита велим

Стерија, Дична звездо, јарко суние 
3.4. У рукописне песмарице спорадично су бележени стихови на немачком, латинском, мађарском, словачком и словеначком језику. Изворе ових бележења потребно је тек открити, а сврху испитати. Ова истраживања могла би да упуте на претпостављене стране изворе и узоре грађанског песништва.

3.5. Да ли ће једна песма, без обзира на то да ли се ради о уметничкој, народној или грађанској, постати популарна и да ли ће се с њеном поетском поруком и обликом идентификовати више људи, у толикој мери да пожеле да је стално имају уза се, зависило је од сплета околности, историјских, социјалних, културних, литерарних и психолошких. Дејство је тих околности највећим делом још неразјашњено, али се може бар наговестити.

a) Једном створена традиција - посматрано у временском распону за који сам се определила у овом раду то значи традиција рукописних збирки насталих до 1830. године - делује у правцу дужег очувања једне песме, снагом сопствене инерције. Ово је, уосталом, карактеристика опстанка рукописних песмарица: ако се за ове настале пре 1817. године може рећи да су резултат опозиције према црквеном и званичном песништву и да су постојале зато што је штампана реч била реткост, ови разлози не важе након 1848. године, доцније још мање, или им је важност сасвим умањена, а рукописне песмарице трају и даље. Све што је створено и честим преписивањем постало део традиционалног фонда не преживљава, један део песама неумитно пада у заборав, али се то не деси никада одједном, а заборављање никада није сасвим радикално.

б) Обичају преписивања из песмарице у песмарицу и преношењу усменим путем прикључује се (и потискује их) обичај преписивања стихова из књига и других публикација. Творевина која је штампана има у принципу више шансе да буде спасена од заборава. Заправо, средином XIX века развој рукописних песмарица иде у овом правцу: по угледу на рукописне песмарице ствара се посебна врста књиге, најчешће такође називана песмарицом, а рукописни зборници стварају се и даље, односно постоји узајамни утицај рукописне и штампане књиге. Нарочито омиљене биле су Забавна песмарииа Јеремије О. Караиића (Београд, 1854) и три, по садржају скоро идентичне Песмарище (Нови Сад, 1862, 1865, 1870), а рекла бих да се много преписивало и из Српског славуја, календара Рyжииа, Бачке виле, Пештанско-будимског скоротече и Серпског народног листа, као и из Вукових збирки. Од четврте деценије XIX века међусобни утицаји рукописних и штампаних песмарица преплићу се: штампане песмарице црпе грађу из рукописних и повлађују укусу њихових власника, али истовремено стварају другачији укус и селектирају песме. 
в) Сви жанрови и све теме нису на једнакој цени. Да би постала популарном, песма мора да се уклопи у жанровски систем и тематске оквире рукописних песмарица.

г) У неким је случајевима на популарност песме утицала популарност дела из кога је истргнута. Тако су све песме М. Видаковића које су бележене у рукописне песмарице преузете из његових романа Велимир и Босиљка и Љубомир у Јелисијуму, а најпопуларнија Стеријина Сакриј бледе своје зраке из романа Бој на Косову. ${ }^{8}$ Изгледа да је и позоришно извођење доприносило већој распрострањености песме. Из Стеријиног Сна Кралевића Марка преузета је у рукописне песмарице песма Устај, устај Србине, а има индиција да су неке песме грађанске лирике редитељском интервенцијом постајале део позоришног извођења, односно да су певане пре или након представе.

д) Прихватљива и прихваћена мелодија погодовала је усменом ширењу и лакшем запамћивању песме. Поуздано се зна, рецимо, да су све популарне песме В. Живковића имале мелодију, као и Стеријине Сакриј бледе твоје зраке и Устај, устај, Србине. Мелодије неких песама биле су толико добро знане да су уз нову песму у рукописним песмарицама само записивали по којој се мелодији може певати.

4. Ако се књижевна историографија конципира као изучавање врхунских остварења и песника који својим делом значе мање-више радикалан преврат у виђењу света и обликовању те визије, сврхе изучавања рукописних песмарица нема. Песништво које је неговано у рукописним песмарицама има атрибуте онога што бисмо данас називали тривијалном литературом: било је у опреци са естетским мерилима које је нудила школа или литература устоличена у часописима и књигама, чак и онда кад је одатле црпело део своје грађе; било је популарно и синкретично, имало је сопствену традицију; није марило за ауторство и оригиналност, што не значи да се у рукописним песмарицама не би могло пронаћи песама које би одговарале савременим критеријумима вредновања. Ако се историја књижевности схвати на неки други начин, ако не као изучавање свеукупности књижевних појава, а оно бар као изучавање свега што је трајало релативно дуго и било од значаја и утицаја. У своме времену, има смисла наставити проучавање рукописних песмарица. Оне су сведочанство о развоју укуса и документ за културну историју, по њима се може

${ }^{8}$ Песма Сакриј бледе твоје зраке само је Стеријин превод, како је открио М. Флашар (вид. Начело мимесе и стваралачки плагијат. О Стерији и о два схватаға списателькко посла, Зборник Матице српске за књижевност и језик, XXIX/2, 1981, 187-188). 
утврђивати популарност једних и запостављеност других песника. Изучавање стилских значајки песама које су преписивањем ширене могло би да покаже истовременост постојање различитих стилских формација и њихово прожимање. Оне су, најзад, вредна грађа за проучавање историје књижевног језика.

* Рад је претходно објављен у зборнику Научни састанак слависта у Вукове дане, 12/2, 175-185. 